Anita Afriani Sinulingga, Abdul Halim, Putiviola Elian Nasir | Bencana dan Konflik: Pelajaran dari Aceh dan Sri Lanka

Article

\title{
Bencana dan Konflik: Pelajaran dari Aceh dan Sri Lanka
}

\author{
Anita Afriani Sinulingga ${ }^{1}$, Abdul Halim ${ }^{2}$, Putiviola Elian Nasir ${ }^{3}$ \\ ${ }^{13}$ Universitas Andalas, Padang \\ ${ }^{2}$ Universitas Sriwijaya, Palembang
}

\section{SUBMISSION TRACK}

$\begin{array}{ll}\text { Received } & : 02 \text { April } 2020 \\ \text { Final Revision } & : 06 \text { October } 2020 \\ \text { Available Online } & : 30 \text { November } 2020\end{array}$

\section{KEYWORD}

Disaster, Conflict, Peace, Aceh, Sri Lanka

\section{KATA KUNCI}

Bencana, Konflik, Perdamaian, Aceh, Sri Lanka

\section{CORRESPONDENCE}

E-mail : anitaafriani@soc.unand.ac.id

\section{A B S T R A C T}

Several academic studies have given birth to the notion that natural disasters and conflicts have a close relationship. Under certain conditions, the disaster functions to bring peace in conflict areas. However, it has not explained how the peace process can affect the dynamics of conflict. This paper aims to analyze the factors that cause conflict in a disaster area to transform into peace or vice versa. The prolonged social conflicts in the Indonesian provinces of Aceh (1976-2005) and Sri Lanka (1983-2009) are examples of cases where the tsunami disaster in December 2004 led to a peace agreement in Aceh, which was not long in the future while failing to bring peace to Sri Lanka. The research conduct with descriptive qualitative methods and internet-based literature study techniques. This paper finds that disaster is a catalyst for the peace process, not determining peace. The transformation of conflict into peace influence by four factors: poverty, state capacity, negotiations, and internationalization of conflicts. These factors that can create peace also depend much on pre-disaster and post-disaster peace efforts.

\section{A B S T R A K}

Beberapa kajian akademik telah melahirkan pemikiran bahwa bencana alam dan konflik mempunyai hubungan yang erat dimana di dalam kondisi tertentu bencana berfungsi membawa damai di wilayah konflik. Namun belum secara detail dijelaskan bagaimana proses perdamaian tersebut dapat mempengaruhi dinamika konflik. Tulisan ini bertujuan untuk menganalisis faktor-faktor yang menyebabkan konflik di wilayah bencana dapat bertransformasi menjadi perdamaian atau sebaliknya. Konflik sosial yang berkepanjangan di provinsi Indonesia di Aceh (1976-2005) dan Sri Lanka (1983-2009) merupakan contoh kasus dimana bencana tsunami pada Desember 2004 mengarah ke perjanjian damai di Aceh dalam waktu yang tidak lama sementara gagal membawa perdamaian Srilanka. Penelitian dilaksanakan dengan metode kualititaf deskriptif dan teknik studi kepustakaan berbasis internet. Tulisan ini menemukan bahwa bencana adalah sebuah katalis bagi proses perdamaian, bukan faktor penentu perdamaian. Transformasi konflik menjadi perdamaian dipengaruhi oleh empat faktor yaitu faktor kemiskinan, kapasitas negara, negosiasi, internasionalisasi konflik. Faktor-faktor tersebut mampu menciptakan perdamaian juga sangat tergantung upaya perdamaian pra-bencana dan pascabencana. 


\section{Pendahuluan}

Bencana alam dan konflik merupakan dua spektrum yang saling mempengaruhi. Bencana alam menimbulkan konflik sosial dalam masyarakat dan menyebabkan berbagai kelangkaan akses berbagai sumber daya. Homer Dixon menjelaskan bahwa perubahan lingkungan yang merupakan cikal bakal bencana alam. Perubahan iklim, penipisan lapisan ozon, degradasi lahan pertanian, deforestasi, kerusakan sumberdaya air dan menipisnya stok ikan menyebabkan kelangkaan akses atas kebutuhan dasar masyarakat. Kelangkaan tersebut merupakan sebab awal terjadinya konflik karena tidak terpenuhinya kebutuhan manusia dalam konteks individu dan masyarakat secara umum $^{1}$. Sejalan dengan pemikiran sebelumnya, Brancati menemukan bahwa bencana alam atau guncangan lingkungan dapat membentuk kelangkaan atas sumberdaya yang sangat penting, frustasi, rasa takut, kemiskinan, marginalisasi dan kecemasan eksternal lainnya yang dapat menjadi pemicu terjadinya sebuah konflik ${ }^{2}$. Slettebak memperkuat penjelasan korelasi antara gempa bumi sebagai sebuah bencana alam terhadap peningkatan tendensi konflik. Hal ini didasarkan pada temuan dari sebuah analisis statistika pada 185 negara dari tahun 1975 hingga 2002 yang memperlihatkan bencana gempa bumi menjadi stimulan adanya kecenderungan peningkatan intensitas konflik di 185 negara tersebut ${ }^{3}$.

Berbagai penelitian menyepakati bahwa kelangkaan atas akses dan sumberdaya pascabencana yang terjadi yang

\footnotetext{
${ }^{1}$ Thomas Homer-Dixon. 1999. Environment, Scarcity and Violence. Princeton: Princeton University Press.

${ }^{2}$ Dawn Brancati. 2007. Political Aftershocks: The impact of Earthquakes on Intrastate Conflict. Journal of Conflict Resolution. Vol.51 No.5 hal 715-743.

${ }^{3}$ Rune T Slettebak. 2012. Don't blame the weather! Climate-related natural disasters and civil conflict. Journal of Peace Research Vol.41 No.3 163-176.
}

membuat masyarakat mengalami kondisi sulit dalam memenuhi kebutuhannya. Ketidakmampuan atas pemenuhan kebutuhan inilah yang kemudian menjadi pemicu lahirnya konflik dan kekerasan. Umumnya bencana alam yang tidak mampu dikelola dengan baik oleh negara akan menjadi pemicu dan menyebabkan konflik dalam masyarakat terdampak bencana. Asumsiasumsi tersebut telah teruji dengan beberapa penelitian akademik, akan tetapi masih belum banyak yang mengkaji faktor-faktor pra-kondisi konflik di wilayah yang sedang mengalami situasi konflik dan bencana alam. Faktor-faktor pra-kondisi tersebut akan melahirkan dua kemungkinan, pertama dengan adanya bencana alam, maka situasi konflik akan cenderung menuju kearah perdamaian, sementara yang kedua, bencana alam akan memperburuk kondisi konflik. Faktor-faktor tersebut yang mempengaruhi apakah konflik akan membawa hasil yang konstruktif, atau sebaliknya menjadi lebih destruktif dari sebelumnya.

Dalam menjelaskan relasi konflik sosial dan bencana, Klitzsch meyakini bahwa bencana dapat menjadi katalis terhadap dinamika konflik, khususnya dalam membawa perdamaian ${ }^{4}$. Bencana dan kebutuhan atas bantuan kemanusiaan, menurut Klitzsch, seharusnya mampu mempertemukan para aktor yang berseberangan dalam upaya bersama untuk bantuan kemanusiaan, proses rekonstruksi dan resolusi konflik. Senada dengan hal tersebut, Siddiqi menambahkan bahwa terdapat paradoks dalam perdebatan mengenai bencana di daerah konflik dimana bencana dapat dilihat sebagai pengganda ancaman, di sisi yang lain, bencana dapat dimaknai sebagai pertanda perdamaian

\footnotetext{
${ }^{4}$ Nicole Klitzsc. 2014. Disaster Politics or Disaster of Politics? Post-tsunami Conflict Transformation in Sri Lanka and Aceh, Indonesia. Cooperation and Conflict Vol. 49, No.4. 554-572
} 
melalui diplomasi bencana ${ }^{5}$. Studi mengenai apakah bencana mengarah kepada perdamaian biasanya ditandai dengan kejadian bencana diikuti dengan perjanjian damai antara pihak-pihak yang bertikai yang ditandatangani selama periode yang sama. Le Billon dan Waizenegger menyampaikan bahwa penting untuk melakukan pembentukkan kembali 'ruang-ruang yang dapat diatur' setelah bencana untuk melakukan transformasi konflik $^{6}$. Namun tidak ada konsensus umum tentang apakah bencana alam meningkatkan konflik atau perdamaian. Seperti yang dijelaskan oleh Kelman bahwa terdapat kesepakatan yang luas diantara para sarjana bahwa terjadinya bencana dapat menyebabkan gencatan senjata sementara, karena kebutuhan untuk bantuan kemanusiaan dan hancurnya fasilitas infrastruktur serta hilangnya personil militer. Namun hal ini tidak berlanjut atau menghasilkan perdamaian jangka panjang ${ }^{7}$. Studi-studi pendahuluan ini membantu untuk melihat bahwa ada hubungan antara bencana dan konflik namun penting ditemukan faktor-faktor yang menjelaskan proses politik atau sosial yang mendasari interaksi konflik dan bencana.

Konflik sosial yang berkepanjangan di provinsi Indonesia di Aceh (1976-2005) dan Sri Lanka (1983-2009) merupakan contoh kasus yang diangkat menjelaskan bagaimana bencana mempengaruhi kondisi konflik pascabencana. Bencana tsunami pada Desember 2004 mengarahkan konflik kepada perjanjian damai di Aceh, tetapi sebaliknya terhadap Srilanka. Pada Agustus 2005, Indonesia mencapai penyelesaian konflik

\footnotetext{
${ }^{5}$ Ayesha Siddiqi. 2018. Disasters In Conflict Areas: Finding The Politics, Disaster Vol 42 No. S2 p. S161S172

${ }^{6}$ Philippe Le Billon and Arno Waizenegger, 2007.

Peace in the Wake of Disaster? Secessionist Conflicts and the 2004 Indian Ocean Tsunami. Transactions of the Institute of British Geographers Vol. 32 No. 3 p.411 - 427

${ }^{7}$ Illan Kelman. 2016. "Catastrophe and Conflict: Disaster Diplomacy and Its Foreign Policy Implications". Brill Research Perspectives in Diplomacy and Foreign Policy, vol. 1, no. 1, pp. 1-76
}

secara damai ditandai dengan ditandatanganinya Nota Kesepahaman antara Pemerintah Indonesia dan Gerakan Aceh Merdeka (GAM) tidak lama setelah tsunami dan diikuti oleh perdamaian dan proses integrasi politik ke dalam demokrasi Indonesia ${ }^{8}$. Pasca-tsunami, pemerintah Indonesia dan Kelompok GAM hanya membutuhkan waktu sekitar delapan bulan untuk mencapai kesepakatan damai. Berbeda dengan konflik di Aceh, bencana tsunami berhasil menciptakan jeda kemanusiaan serta upaya untuk menciptakan mekanisme bersama antara Pemerintah Sri Lanka dan kelompok pemberontak Macan Pembebasan Tamil Eelam (LTTE) dalam menangani bantuan kemanusiaan. Namun dalam waktu singkat pasca jeda kemanusiaan tersebut, Sri Lanka kembali ke perang dengan skala yang lebih besar.

Dalam penelitiannya, Gaillard dkk menemukan bahwa pasca bencana tsunami, faktor-faktor terkait langsung dengan bencana kurang berpengaruh bagi perdamaian, sebaliknya faktor-faktor politik non-bencana dan faktor-faktor yang bersifat internal cenderung memiliki dampak yang lebih signifikan terhadap penyelesaian jangka panjang konflik ${ }^{9}$. Hal tersebut dibuktikan melalui proses rekonstruksi yang lambat, tidak merata, dan seringkali prosesnya sangat buruk sehingga menghalangi, atau bahkan mengancam, proses perdamaian. Mengambil konflik intra-state Provinsi Aceh di Indonesia dan Sri Lanka sebagai studi kasus dalam tulisan ini diharapkan diperoleh penjelasan mengenai kondisi-kondisi bagaimana bencana mempengaruhi konflik menjadi konstruktif yang mengarah kepada perdamaian atau sebaliknya bersifat konstruktif berakhir pada peningkatan eskalasi konflik yang lebih tinggi.

\footnotetext{
${ }^{8}$ Damien Kingsbury. 2006. Peace in Aceh: A

Personal Account of the Helsinki Peace Process. 2006.

Jakarta: PT Equinox Publishing Indonesia hal 65

${ }^{9}$ Jean-Christophe Gaillard, Elsa Clave, Ilam Kelman. 2008. Wave of Peace? Tsunami disaster diplomacy in Aceh, Indonesia.Geoforum Vol 39 No. 1 hal 511-526
} 


\section{Metode Penelitian}

Tulisan ini didasarkan pada metode penelitian kualitatif dan didisain berupa penelitian studi kasus. Creswell dalam Moleong menjelaskan disain riset seperti ini bermanfaat untuk mempelajari fenomena sosial dengan tujuan menjelaskan dan menganalisa perilaku manusia dan kelompok, dari sudut pandang yang sama sebagai objek yang diteliti melihat masalah tersebut ${ }^{10}$. Jenis penelitian ini lebih fokus pada makna (meaning) dan pemahaman (understanding) daripada kuantifikasi. Christoper Lamont menjelaskan metode penelitian kualitatif digunakan untuk memahami dunia di sekitar kita dan oleh sebab tipe penelitian ini lebih fokus pada makna dan proses yang membentuk hubungan internasional ${ }^{11}$. Sumber data penelitian adalah artikel dan jurnal ilmiah dan buku serta berbagai laporan resmi dikumpulkan melalui penelusuran berbasis internet.

Dua daerah yang paling parah terkena tsunami dan juga dilanda konflik sosial, Aceh dan Sri Lanka, merupakan objek penelitian yang diangkat dalam tulisan ini. Konflik dan bencana di wilayah ini bertumpang-tindih. Ketika bencana terjadi, Aceh sedang menghadapi persoalan separatisme yang telah bergejolak sejak 1976 . Sebagai wilayah zona perang, Aceh telah dimiliterisasi secara besar-besaran dengan ditempatkannya 40.000 tentara sejak ditetapkannya status darurat militer pada bulan Mei 2003. Sri lanka, wilayah lain yang juga dilanda bencana, disebut sebagai daerah yang tidak jelas/ uncleared areas yang berada di sepanjang pantai yang dikontrol oleh Organisasi Pembebasan Macan Tamil Eelam $(\mathrm{LTTE})^{12}$. Hal ini menyebabkan

\footnotetext{
${ }^{10}$ Lexy.J. Moleong. 2000. Metodologi Penelitian Kualitatif. Bandung: PT Remaja Posdakarya. hal 3 ${ }^{11}$ Christopher Lamont. 2015. Research Methods in International Relations. London: SAGE Publications Ltd

12 Eva-Lotta Hedman. The Politics Of The Tsunami Response dalam Forced Migration Review, Tsunami:
}

kedua negara mengalami dua kerusakan secara bersamaan yaitu kerusakan akibat bencana alam dan kerusakan akibat konflik.

Yang berbeda adalah konflik sosial di Aceh, besarnya skala bencana menjadi bagian dari perdamaian pada 15 Agustus 2005 antara pemerintah Indonesia dan kelompok Gerakan Aceh Merdeka (GAM), sementara di Sri Lanka, bencana besar ini tidak melahirkan itikad perdamaian ${ }^{13}$. Satu bulan setelah tsunami, Pemerintah Indonesia dan GAM meluncurkan negosiasi resmi, setelah pembicaraan informal di bawah Wakil Presiden Jusuf Kalla dimulai sebelum tsunami dan kedua belah pihak telah sepakat untuk bertemu untuk negosiasi damai yang difasilitasi oleh mantan Presiden Finlandia Martti Ahtisaari. GAM menurunkan tuntutannya untuk kemerdekaan dan mendapat kewenangan pemerintahan sendiri atas Aceh serta memperoleh pemantauan yang dipimpin Uni Eropa dalam proses transisi. Setelah GAM dan Pemerintah Indonesia secara resmi menandatangani Nota Kesepahaman (MoU) pada tanggal 15 Agustus 2005, Dewan Perwakilan Rakyat Indonesia mengesahkan UU baru tentang Pemerintahan Aceh (UUPA) ${ }^{14}$.

Di Sri Lanka, perjanjian gencatan senjata tahun 2002 telah menangguhkan perang saudara, tetapi fokus proses perdamaian ditempatkan pada rekonstruksi dan pembangunan pasca-konflik daripada negosiasi substantif atas isu-isu politik inti ${ }^{15}$. Pasca tsunami di Sri Lanka ditandai dengan niat baik dari kepemimpinan di kedua sisi dan spontanitas untuk bekerjasama antara

Learning From The Humanitarian Response, Special Issue July 2005, hal 5

${ }^{13}$ Patrick Daly dkk. Aceh Pascatsunami dan PascaKonflik. KITLV-Jakarta, 2012, hal vii

${ }^{14}$ Patrick Barron dan Samuel Clark. 2006. "Decentralizing Inequality? Center-Periphery Relations, Local Governance, and Conflict in Aceh," Conflict Prevention and Reconstruction Paper No. 39. Washington, D.C.: World Bank.

${ }^{15}$ Jonathan Goodhand dan Bart Klem. 2005. Aid, Conflict, and Peacebuilding in Sri Lanka 2000-2005. Sri Lanka: The Asia Foundation 
Anita Afriani Sinulingga, Abdul Halim, Putiviola Elian Nasir | Bencana dan Konflik: Pelajaran dari Aceh dan Sri Lanka

Tabel 1 Persamaan dan perbedaan kasus Aceh dan Sri Lanka

\begin{tabular}{|c|c|c|}
\hline Negara & Indonesia & Sri Lanka \\
\hline Jenis Kejadian & $\begin{array}{l}\text { Tsunami Samudera Hindia: } 26 \\
\text { Desember } 2004\end{array}$ & \begin{tabular}{|lll} 
Tsunami Samudera & Hindia: & 26 \\
Desember 2004 & & \\
\end{tabular} \\
\hline Dampak bencana & $\begin{array}{l}\text { - } 130.000 \text { orang meninggal } \\
\text { - } \text { Kerusakan dan kehilangan sebesar } \\
\text { US } \$ 4,5 \text { miliar } \\
\text { - } \text { Mempengaruhi } 97 \% \text { PDB provinsi } \\
\text { atau } 2 \% \text { PDB nasional }\end{array}$ & $\begin{array}{l}\text { - } 35.322 \text { orang tewas } \\
\text { - } \text { Kerusakan dan kehilangan sebesar } \\
\text { US \$ 2,2 miliar } \\
\text { - }\end{array}$ \\
\hline Dampak konflik & 15.000 orang tewas akibat konflik & $\begin{array}{l}390.000 \text { orang mengungsi dalam lebih } \\
\text { dari } 20 \text { tahun konflik }\end{array}$ \\
\hline Isu konflik & $\begin{array}{l}\text { Separatisme (otonomi dan penentuan } \\
\text { Nasib Sendiri }\end{array}$ & $\begin{array}{l}\text { Separatisme (otonomi dan penentuan } \\
\text { Nasib Sendiri }\end{array}$ \\
\hline Dinamika konflik & Perdamaian & Konflik berlanjut dan memburuk \\
\hline
\end{tabular}

Sumber: diolah oleh peneliti dari berbagai sumber

pemerintah Sri Lanka dan pasukan LTTE $^{16}$. Beberapa pihak yang berperang bahkan pada awalnya menganggap tsunami sebagai berkah terselubung terhadap proses penyelesaian konflik, tetapi permusuhan meningkat dalam waktu satu tahun. Politisasi bantuan bencana juga merusak perjanjian gencatan senjata yang sudah ada sebelumnya ${ }^{17}$. Meskipun perjanjian gencatan senjata telah ada, namun kelompok pemberontak LTTE yang telah menarik diri dari negosiasi dengan pemerintah pada tahun 2003, selanjutnya melakukan serangan militer pada awal 2005. Hal ini menyebabkan LTTE dan pemerintah kembali kepada kondisi kekerasan. Penjelasan mengenai konflik dan bencana yang dialami oleh Aceh dan Sri Lanka dapat dilihat pada tabel 1 .

\section{Hasil dan Pembahasan}

Bencana dijelaskan oleh Quarantelli ke dalam tiga perspektif. Pertama, bencana dijelaskan menjadi pemicu terjadinya perang di sebuah daerah yang terkena bencana. Kedua, bencana dipahami sebagai sebuah kerentanan sosial. Bencana alam dapat

\footnotetext{
${ }^{16}$ Jayadeva Uyangoda. 2005. Ethnic conflict, the state and tsunami disaster in Sri Lanka Inter-Asia Cultural Studies No. 6 Vol.3 hal 341-52

${ }^{17}$ Kristian Stokke. 2005. After the tsunami: a missed opportunity for peace in Sri Lanka? NIASnytt Asia Insights Vol 2 hal 12-13
}

dianggap sebagai sebuah kerentanan sosial ketika dampak sosial yang tidak dapat dihindarkan tidak mampu diorganisir dengan baik. Dalam hal ini, kata kunci bencana adalah kerentanan sosial. Terakhir, bencana dapat lagi dikelompokkan menjadi dua bagian yaitu bencana sebagai sebuah kejadian yang aksidensial dan bencana merupakan sebuah hasil dari kondisi krisis yang tidak dapat terselesaikan ${ }^{18}$ Menguatkan bagian ketiga ini, Collins membagi bencana menjadi natural disaster atau bencana yang disebabkan langsung oleh alam dan manmade disaster dimana bencana terkait dengan aktivitas atau perilaku manusia. Collins menjelaskan lebih jauh bahwa bencana terjadi akibat runtuhnya budaya perlindungan ${ }^{19}$. Bencana memiliki kaitan yang sangat erat dengan konflik, apakah akan membawa kondisi-kondisi yang bersifat konstruktif dimana konflik berakhir dengan perdamaian, atau bersifat destruktif, dimana konflik akan berulang dengan skala yang lebih besar, seperti yang terjadi dalam kasus konflik Aceh dan Sri Lanka.

\footnotetext{
${ }^{18}$ Enrico Louis Quarantelli. 1998. What is a Disaster? Perspectives in the Question. London and New York: Routledge.

19 Andrew E. Collins. 2009. Disaster and Development. New York: Routledge.
} 
Anita Afriani Sinulingga, Abdul Halim, Putiviola Elian Nasir | Bencana dan Konflik: Pelajaran dari Aceh dan Sri Lanka

\section{Bencana, Konflik dan Kemiskinan}

Ketika gelombang tsunami menerjang Sri Lanka, negara ini sama sekali tidak siap menghadapi bencana dengan skala dan ukuran yang besar, meskipun negara ini mengalami musim kemarau panjang secara periodik, banjir, tanah longsor dan kadangkadang badai, sehingga jumlah korban jiwa dan kerusakan akibat bencana tsunami menjadi tidak terhindarkan. Sri Lanka tidak memiliki sistem peringatan bahaya domestik yang efektif dan tidak menganggap perlu menjadi bagian dari sistem peringatan dini internasional, seperti Sistem Peringatan Tsunami di kawasan Pasifik yang melibatkan dengan 26 negara anggota. Saat diterpa bencana, Sri Lanka juga sedang mengalami tekanan di sektor makro ekonominya. Parahnya bencana tsunami di Propinsi Utara dan Timur, yang merupakan wilayah dikuasai kelompok LTTE, memperburuk masalah yang diakibatkan oleh konflik yang telah berlangsung. Hilangnya jiwa dan sumber mata pencaharian, menyebabkan tingkat kemiskinan di banyak distrik di garis pantai ini lebih tinggi daripada tingkat nasional. Bagi masyarakat yang menjadi korban bencana di bagian wilayah kekuasaan kelompok LTTE tersebut, masalah dampak bencana tsunami memperberat lagi beban marginalisasi yang sebelumnya sudah ada sebagai akibat konflik yang berlangsung selama dua dasawarsa. Hal ini menyebabkan upaya membangun kembali kehidupan di bagian utara dan timur Sri Lanka bukan saja mengatasi dampak bencana tsunami, tetapi juga warisan konflik yang sudah lama berlangsung. Sejak kemerdekaan pemerintah bersama berbagai stakeholder di Sri Lanka telah mencoba berbagai program untuk mengatasi kemiskinan di Sri Lanka namun hasilnya di Sri Lanka sekitar seperempat penduduk masih hidup di bawah garis kemiskinan $^{20}$.

\footnotetext{
${ }^{20}$ Sisira Jayasuriya dkk, 2006. Pemulihan PascaTsunami: Masalah dan Tantangan di Sri Lanka, Jepang: Asian Development Bank Institute
}

Persoalan mekanisme distribusi bantuan ke daerah yang dikuasai oleh LTTE menjadi masalah lain yang sulit disepakati. Pemerintah Sri Lanka dalam hal ini bersedia memberikan pengakuan de facto kepada LTTE sebagai kuasa administratif di daerah yang dikuasainya. Namun LTTE tidak bersedia menerima persetujuan tersebut karena dilihat mengurangi kekuasaan kelompok tersebut. Melalui berbagai perundingan, pada bulan Juni 2005 ditandatanganilah $\mathrm{MoU}$ yang menjelaskan persetujuan mengenai pembagian bantuan antara Pemerintah Sri Lanka dan kelompok LTTE yang disebut Struktur Pengelolaan Operasi Pasca-Tsunami. Hal ini dirancang sebagai suatu mekanisme untuk membagikan bantuan di daerah-daerah yang dikuasai oleh LTTE di Propinsi Utara dan Timur negara ini serta memungkinkan donor menyalurkan dana tsunami langsung ke Propinsi Utara dan Timur Sri Lanka. Namun persetujuan ini mendapat pertentangan dari kelompok masyarakat Sinhala. Selain itu, banyak dari donor utama yang sedianya mendukung gagasan mekanisme untuk membagi bantuan antara Pemerintah Sri Lanka dan LTTE akhirnya menolak menyalurkan bantuan langsung pasca penandatanganan MoU. Lembaga donor tersebut menyatakan bahwa LTTE tetap dianggap sebagai organisasi teroris terlarang di negaranya ${ }^{21}$.

Sementara itu, bencana tsunami menghancurkan kehidupan masyarakat Aceh, yang sebelumnya telah mengalami penderitaan sebagai dampak dari konflik selama 30-tahun dan menjadi salah satu provinsi termiskin di Indonesia pada tahun 1970-an, meskipun Aceh kaya akan gas dan sumber daya alam lainnya. Angka kemiskinan secara keseluruhan di Aceh pada tahun 2004 yaitu 28,4\%, sebuah angka yang jauh lebih tinggi daripada tingkat kemiskinan nasional Indonesia yaitu sebesar 16,7\%. Pascatsunami, tingkat kemiskinan meningkat

\footnotetext{
21 Sisira Jayasuriya dkk, 2006. Pemulihan PascaTsunami: Masalah dan Tantangan di Sri Lanka, Jepang: Asian Development Bank Institute
} 
khususnya di wilayah-wilayah yang terkena dampak bencana maupun konflik. Meskipun angka kemiskinan sedikit meningkat pada tahun 2005 selanjutnya menurun pada tahun 2006, dampak kemiskinan akibat tsunami tidak seragam di berbagai wilayah Aceh. Pada 2006, tingkat kemiskinan di seluruh Aceh, termasuk yang terkena dampak bencana, menurun ditandai dengan data kemiskinan wilayah-wilayah sekitar Banda Aceh, wilayah terkena dampak tsunami, memiliki tingkat paling rendah. Respon global terhadap tsunami dan melimpahnya bantuan kemanusiaan sekitar 7,5 milyar dolar AS dalam jangka waktu lima tahun, menyebabkan perekonomian telah pulih dengan cepat dalam jangka waktu yang relatif singkat ${ }^{22}$.

Dari penjelasan sebelumnya, bencana tsunami menyebabkan peningkatan kemiskinan yang relatif kecil di Aceh. Sebaliknya konflik selama 30 tahun telah menimbulkan kerusakan yang besar di Aceh. Aspinall memperkirakan bahwa sekitar 15.000 orang meninggal selama 30 tahun berlangsungnya konflik ${ }^{23}$. Meskipun Aceh merupakan provinsi yang kaya akan sumber daya alam, namun perekonomiannya tumbuh lebih lambat dibandingkan wilayah lain di Indonesia. Aceh merupakan satu-satunya provinsi dengan angka kemiskinan yang terus meningkat setelah tahun 2000, sebagaimana konflik Aceh memasuki tahap ketiga dan merupakan tahap paling brutal yang telah mengubah Aceh menjadi salah satu provinsi termiskin di Indonesia ${ }^{24}$.

Theisen dkk menjelaskan sumberdaya alam berpotensi dalam peningkatan tendensi konflik di daerah

\footnotetext{
${ }^{22}$ Bank Dunia. 2008. Dampak Konflik, Tsunami dan Rekonstruksi terhadap Kemiskinan di Aceh: Kajian Kemiskinan di Aceh tahun 2008. Jakarta: Bank Dunia. hal 8

23 Aspinall, Edward, 2005, "The Helsinki Agreement: A More Promising Basis for Peace in Aceh?', Policy Studies n20, East-West Center Washington DC

${ }^{24}$ Bank Dunia. 2008. Dampak Konflik, Tsunami dan

Rekonstruksi terhadap Kemiskinan di Aceh: Kajian

Kemiskinan di Aceh tahun 2008. Jakarta: Bank Dunia
}

bencana. Praktik-praktik penguasaan dan monopoli sumberdaya alam oleh kelompok pemberontak yang kemudian digunakan untuk membiayai persenjataan dan rencana strategis untuk mendapatkan kepentingan lain dalam kontestasi konflik yang dipertahankan Selanjutnya dalam kondisi ini diasumsikan kondisi konflik cenderung memburuk. Sementara itu jika jumlah sumberdaya alam yang dimiliki daerah konflik sedikit maka konflik cenderung menurun disebabkan pembiayaan terhadap konflik dan perang sudah sangat minim sebagai dampak dari kondisi pascabencana ${ }^{25}$. Sementara Slettebak menjelaskan tingkat kemiskinan memainkan peran yang cukup signifikan dalam konflik. Kemiskinan juga menjadi landasan dasar terjadinya konflik sosial dalam masyarakat. Dapat dilihat bahwa sebuah daerah yang berkonflik memiliki kecenderungan terhadap tingkat kemiskinan yang tinggi. Hal ini didasarkan pada ketidakmampuan pemenuhan kebutuhan hidup. Dengan kondisi tersebut ditambah dengan bencana alam yang datang, maka tendensi konflik akan semakin memanas $^{26}$.

Dari konflik Aceh dan Sri Lanka dapat dipahami bahwa peristiwa bencana alam yang diikuti dengan kemiskinan menyebabkan kekuatan dari pihak pemerintah dan kelompok pemberontak menjadi menurun. Khususnya pada wilayahwilayah dikuasai kelompok pemberontak, menjadi salah satu wilayah mengalami kerusakan yang tinggi sebagai dampak bencana. Hal ini diperburuk dengan masalah ekonomi yang juga terjadi di wilayah tersebut sebagai akibat dari konflik yang berkepanjangan sebelum bencana. Masalah ekonomi tersebut selanjutnya berujung pada masalah finansial yang dialami oleh

\footnotetext{
${ }^{25}$ Ole Magnus Theisen, Helge Holtermann \& Halvard Buhaug. 2012. "Climate Wars? Assessing the Claim That Drought Breeds Conflict. International Security No.36 Vol.3 hal 79-106

${ }^{26}$ Rune T Slettebak. 2012. Don't blame the weather! Climate-related natural disasters and civil conflict. Journal of Peace Research Vol.41 No.3 163-176.
} 
kelompok pemberontak dalam pembiayaan dalam peristiwa konflik. Masalah bencana dalam hal ini telah melemahkan kekuatan aktor yang berkonflik, dalam hal ini berada pada pihak kelompok pemberontak, sementara kekuatan aktor pemerintah cenderung lebih stabil, diperkuat dengan bantuan internasional yang datang dalam jumlah dan skala yang sangat besar. Khususnya dalam kasus Aceh, kondisi tersebut jelas telihat. Bencana tsunami memberikan dorongan psikologis bagi para prajurit GAM yang sudah dilemahkan oleh Daerah Operasi Militer (DOM) untuk mencari perdamaian. Penjelasan ini sejalan dengan yang disampaikan oleh Kelman bahwa bencana dapat menyebabkan gencatan senjata sementara antara kelompokkelompok yang berkonflik karena kebutuhan untuk bantuan kemanusiaan dan hancurnya fasilitas infrastruktur serta hilangnya personil militer. Namun kondisi ini belum efektif untuk proses perdamaian jangka panjang ${ }^{27}$.

\section{Kapasitas Negara dalam Mengelola Konflik dan Bencana}

Kehadiran negara dalam menyusun regulasi mengenai penanggulangan bencana sangat dibutuhkan oleh wilayah yang mengalami bencana. Perdamaian berpeluang ketika negara mempunyai kapasitas menyusun tata kelola bencana. Sebaliknya, jika pemerintah cenderung lamban dan salah mengambil tindakan serta kebijakan, maka konflik akan memburuk dan jalan perdamaian akan terhambat ${ }^{28}$. Jika memperhatikan kapasitas pemerintah kedua negara dalam menyelesaikan konflik etnis, proses perdamaian di Indonesia pasca tsunami dinilai lebih berpengaruh positif

27 Illan Kelman. 2016. "Catastrophe and Conflict: Disaster Diplomacy and Its Foreign Policy Implications". Brill Research Perspectives in Diplomacy and Foreign Policy, vol. 1, no. 1, pp. 1-76

${ }^{28}$ Rune T Slettebak. 2012. Don't blame the weather! Climate-related natural disasters and civil conflict. Journal of Peace Research Vol.41 No.3 163-176. dibandingkan dengan Sri Lanka. Salah satu alasan kegagalan proses perdamaian di Sri Lanka adalah kenyataan bahwa pemerintah yang menandatangani proses perdamaian adalah pemerintah minoritas sehingga karena tidak mengendalikan semua pihak di dalam negaranya. Dalam kasus penandatanganan MoU terkait pembagian bantuan antara Pemerintah Sri Lanka dan LTTE menyebabkan pemerintah kehilangan suara mayoritasnya di parlemen. Ketika salah satu partai pendukung pemerintah, Janatha Vimukthi Peramuna (JVP),

meninggalkan pihak koalisi pemerintah. Pada tahap selanjutnya, terpilihnya presiden baru yang secara terbuka menentang kemudian menghapuskan kebijakan tersebut 29.

Di Indonesia, di sisi lain, pemerintahan baru Susilo Bambang Yudhoyono jauh lebih kuat dan kohesif dalam masalah perdamaian di Aceh. Pemerintahan SBY-Kalla mengendalikan lembaga-lembaga utama yang diperlukan untuk memastikan pengesahan UndangUndang tentang Pemerintahan Aceh. Oleh karena itu, tertutupnya jalan perdamaian di Sri Lanka sebagian karena ketidakmampuan pemerintah untuk menawarkan penyelesaian yang bersifat substantif ke daerah-daerah yang dikuasai LTTE, didukung serta ketidaktaatan, ketidaksabaran, dan ketidakmampuan LTTE untuk mengubah dirinya menjadi sebuah organisasi yang lebih demokratis. Hal ini juga berkontribusi pada fakta bahwa bantuan untuk proses perdamaian tidak akan diberikan kepada masyarakat karena peran industri bantuan internasional.

Kondisi-kondisi ini ini mengakibatkan jatuhnya pemerintah yang menandatangani proses perdamaian di Sri Lanka dan membawa kekuasaan pada rezim pemerintah yang mengedepankan perang dan militerisme sebagai solusi untuk konflik. Maka dapat

\footnotetext{
29 Sisira Jayasuriya dkk, 2006. Pemulihan PascaTsunami: Masalah dan Tantangan di Sri Lanka, Jepang: Asian Development Bank Institute. Hal 22
} 
dikatakan bahwa negara-negara seperti Indonesia dan Sri Lanka berada di jalur berbeda, yang satu bergerak ke arah demokratisasi, sementara yang lain, menuju militerisasi yang lebih besar dan sentralisasi yang bergerak menjauh dari kerangka kelembagaan yang lebih demokratis. Diskusi mengenai dampak dan respon negara terhadap bencana hampir tidak pernah dikaitkan dengan isu-isu negara-negara 'predator' atau neoliberal dan cara dimana mereka mampu untuk memobilisasi bencana untuk kepentingan politik. Secara politis, bencana sering disebut sebagai katalisator, jendela peluang atau titik kritis untuk perubahan sosial di sebuah negara. Kondisi kritis seperti bencana mengubah kontrak sosial antara warga negara dan negara, menyebabkan kedua belah pihak memikirkan kembali hubungan keduanya ${ }^{30}$. Carrigan menjelaskan respon dan kesiapsiagaan bencana secara konsisten merujuk kepada 'kebaikan hakiki' peran negara daripada mengakui bahwa negara itu sendiri adalah 'bahaya' bagi sebagian besar komunitas masyarakat rentan yang hidup dalam kerentanan $^{31}$.

\section{Proses Negosiasi Perdamaian}

Kelman menjelaskan peluang perdamaian juga dipengaruhi oleh upayaupaya aktor menemukan jalan tengah sebelum terjadinya bencana ${ }^{32}$. Dalam menentukan jalan penyelesaian konflik tersebut diperlukan elemen trust atau kepercayaan yang harus dibangun dan dimiliki oleh tiap aktor yang melakukan

\footnotetext{
${ }^{30}$ Ayesha Siddiqi. Disasters in conflict areas: finding the politics, Disaster vol 42 no.S2 p. S161-S172

31 Anthony Carrigan. 2016 'Towards a postcolonial disaster studies' dalam Elizabeth Deloughery dkk (eds.) Global Ecologies and the Environmental Humanities: Postcolonial Approaches. Abingdon: Routledge. Hal. 117139.

32 Illan Kelman. 2011. Disaster Diplomacy: How disasters affect peace and conflict. London: Routledge.
}

negosiasi $\mathrm{i}^{33}$. Jalannya proses perundingan juga tentunya dipengaruhi oleh oleh karakter dan posisi pihak-pihak yang berkonflik. Wilayah konflik yang telah masuk pada fase perundingan perdamaian cenderung lebih cepat membentuk perdamaian pasca bencana dibandingkan daerah konflik yang belum sama sekali melakukan perundingan di antara para pihak yang berkonflik.

Proses perdamaian baik dalam Aceh dan Sri Lanka tidak terlepas dari peran internasional di dalamnya. Namun pun begitu, proses perundingan antara pihak RIGAM telah dilaksanakan sebelum terjadinya tsunami. Dalam penanggulangan bencana di Aceh, dunia internasional berkomitmen untuk memberikan bantuan ekonomi dan politik menimbang pentingnya posisi Indonesia di dunia internasional pascaperistiwa 9/11 sebagai negara dengan populasi muslim terbesar di dunia. Hampir semua korban tsunami Aceh berada di wilayah konflik. Sulitnya melakukan distribusi bantuan kemanusiaan di wilayah konflik memicu komunitas internasional untuk mengakhiri konflik dan kekerasan di wilayah tersebut. Uni Eropa, negara-negara ASEAN dan para diplomat dunia mendukung pembicaraan damai yang difasilitasi oleh Crisis Management Initiative, sebuah NGO perdamaian dari Finlandia, yang dibentuk Martti Ahtisaari dan dilengkapi dengan Aceh Monitoring Mission. Aliran bantuan internasional mengalir ke Aceh membantu mengkatalisasi Nota Kesepahaman Helsinki (MOU) dan proses perdamaian Aceh yang mulai berlaku enam bulan setelah bencana tsunami. Kontak awal antara Pemerintah Indonesia Yudhoyono yang baru terpilih dan kelompok separatis Gerakan Aceh Merdeka (GAM) telah dimulai sebelum bencana melalui mediator Finlandia. Proses perdamaian Aceh yang dimediasi oleh Finlandia dianggap sebagai salah satu perjanjian perdamaian yang

\footnotetext{
33 Minear, L., \& Smith, H. (2007). Humanitarian Diplomacy Practitioners and Their Craft . New York: United Nations University.
} 
dimediasi secara internasional paling sukses di dunia tetapi tidak menyelamatkan proses perdamaian di Sri Lanka.

Mediasi yang difasilitasi melalui bantuan internasional berkontribusi pada keseimbangan "tidak ada perang, tidak ada perdamaian" di Sri Lanka yang diakhiri dengan kemenangan militer pemerintah ${ }^{34}$. Bencana tsunami dan bantuan internasional berkontribusi pada pemulihan hubungan awal antara Pemerintah Sri Lanka (GoSL) dan Macan Pembebasan Tamil Eelam (LTTE) yang memperjuangkan otonomi terhadap negara, proses perdamaian yang dimediasi oleh Norwegia pada tahun 2001-2008 terbukti tidak berkelanjutan. Runtuhnya proses perdamaian yang difasilitasi Norwegia di Sri Lanka ditandai dengan pertempuran baru yang diakhiri oleh kekalahan militer LTTE pada Mei 2009. Pada minggu kedua Mei 2009, LTTE dikalahkan oleh angkatan bersenjata Sri Lanka dan menyebabkan pemimpin kelompok tersebut terbunuh. Akar penyebab konflik di Sri Lanka sebagian besar masih belum terselesaikan dan keberlanjutan perdamaian di Sri Lanka masih dipertanyakan karena kemungkinan para militan dapat berkumpul kembali dan meminta kembali adanya ganti rugi atas permintaan pembagian kekuasaan oleh Tamil, minoritas di timur laut Sri Lanka. Salah satu alasan utama kegagalan proses perdamaian di Sri Lanka adalah bahwa pemerintah yang menandatangani proses perdamaian dikeluarkan dari jabatannya dan pemerintah baru membatalkan perjanjian perdamaian.

Karakteristik kelompok pemberontak tentunya juga sangat mempengaruhi proses perundingan. GAM, meskipun mengalami perpecahan selama proses perdamaian, adalah organisasi yang lebih fleksibel untuk memulai proses perdamaian, memiliki

34 Darini Rajasingham-Senanayake. 2009. Transnational Peace Building and Conflict: Lessons from Aceh, Indonesia, and Sri Lanka. Journal of Social Issues in Southeast Asia, Vol. 24, No. 2 struktur organisasi yang lebih longgar serta memberikan peluang regenerasi kepemimpinan. Pejuang GAM dimungkinkan bergabung dan meninggalkan organisasi dengan cara yang relatif lancar. Sebagian anggota GAM menjadi petani di siang hari dan pejuang di malam hari. Organisasi ini juga tidak menghilangkan hubungannya dengan masyarakat dan interaksi sosialnya. Berdasarkan kondisi tersebut, GAM lebih merupakan gerakan sosial. Berbeda dengan kelompok GAM, LTTE adalah organisasi yang sangat tersentralisasi dan hierarkis, budaya organisasi LTTE yang sangat kaku, hanya ada Vellupillai Prabakaran, seorang pelaku pembunuhan mantan Perdana Menteri Rajiv Gandhi, sebagai pemimpin LTTE. Dari pada melihat kelompok ini sebagai kelompok separatis, kelompok ini lebih terlihat sebagai kelompok teroris. LTTE saat ini berubah menjadi mesin perang jaringan transnasional dengan kader pembom bunuh diri yang sangat disiplin, terlatih dan berdedikasi, ditopang oleh dana diaspora. LTTE juga membunuh banyak orang Tamil moderat termasuk Pengacara Konstitusi dan Hak Asasi Manusia, Neelan Tiruchlvam, yang sedang bernegosiasi dengan pemerintah Sri Lanka untuk pelimpahan kekuasaan untuk minoritas.

Dalam proses perdamaian di Aceh dan Sri Lanka, telah dilakukan upaya negosiasi sebelum terjadinya bencana, Namun hasil yang diperoleh sangat berbeda dimana konflik GAM-RI berakhir dengan perdamaian sementara konflik pemerintah Sri Lanka-Kelompok LTTE masih berlanjut pasca bencana bahkan hingga saat ini. Harris dalam Klitzsch menyebutkan bencana tsunami tahun 2004 sebagai faktor yang menyediakan jalan menuju jalan keluar dari kebuntuan yang saling menyakiti. Harris menunjukkan bahwa kemungkinan kesuksesan mediasi eksternal dari konflik antar negara lebih tinggi jika para pihak dalam konflik mendefinisikan kembali tujuan mereka, di pihak pemberontak dari pemisahan diri dengan pemerintahan sendiri, 
sementara di pihak pemerintah lawan dari kekalahan dari gerakan pemberontak ke penahanannya. Dalam pandangannya, redefinisi kritis ini didorong oleh bencana tsunami ${ }^{35}$.

Dalam hal ini, proses perdamaian terkait dengan posisi kelompok pemberontak yang dipengaruhi oleh karakter organisasi. GAM dan LTTE memiliki perbedaan kemampuan untuk mengubah diri mereka sendiri selama proses perdamaian. Michel Wieviorka membedakan karakter teroris dan pejuang pembebasan ${ }^{36}$. Wieviorka menjelaskan sebuah kelompok teroris dapat kehilangan hubungan asalnya dengan penyebab asli, apakah isu etnis atau nasional dan/ atau kepentingan komunitas lokal yang diperjuangkannya, dari waktu ke waktu, dan berkembang menjadi jaringan teror transnasional atau mesin perang yang memiliki jaringan global. Tidak dapat dihindari bahwa organisasi-organisasi semacam itu akan terpecah selama transisi menuju perdamaian dan demokrasi. Baik GAM maupun LTTE telah melalui proses fragmentasi selama proses perdamaian. Berbeda dengan Sri Lanka, di Aceh, Komite Transisi Aceh/ KPA, badan yang dibentuk untuk mewakili mantan kombatan GAM dan kelompok lain telah muncul. Konflik telah terjadi antara mantan kelompok GAM dan antara paramiliter yang didukung TNI, khususnya di Aceh Tengah, di mana hegemoni GAM dibatasi karena kelompok etnis lain menginginkan otonomi mereka dari Aceh.

\section{Internasionalisasi Konflik}

Dalam berbagai literatur cukup banyak yang menyakini bahwa bantuan internasional dalam konflik bersenjata internal dapat

\footnotetext{
${ }^{35}$ Nicole Klitzsc. 2014. Disaster Politics or Disaster of Politics? Post-tsunami Conflict Transformation in Sri Lanka and Aceh, Indonesia. Cooperation and Conflict Vol. 49, No.4. 554-572

36 Michel Wieviorka. 2000. Contextualizing French Multiculturalism and Racism. Theory, Culture \& Society. Sage Journal. Vol 17 No. 1
}

memperbaiki proses perdamaian atau menjadi bagian dari siklus konflik baru. Hal ini diperkuat dengan penelitian di Institut Perdamaian Amerika Serikat yang menemukan bahwa dari tiga puluh delapan proses perdamaian yang terjadi dengan bantuan internasional pada dekade 19891999, tiga puluh tiga kembali ke konflik dalam tiga tahun pertama ${ }^{37}$. Dalam situasi seperti Aceh dan Sri Lanka pasca tsunami, terdapat tiga aktor utama dalam menyeimbangkan konflik dan perdamaian yang sangat terinternasionalisasi dimana dua pihak utama yang berkonflik, biasanya negara dan kelompok yang menentangnya, serta, komunitas bantuan internasional. Masyarakat sipil merupakan aktor keempat dan sering dikecualikan dalam proses perdamaian. Hal ini menjadi salah satu alasan kurangnya proses perdamaian yang inklusif dan tahan lama, seperti yang terjadi di Sri Lanka sebagai akibat dari internasionalisasi yang berlebihan adalah kurangnya pembangunan perdamaian yang inklusif serta kepemilikan lokal atas kebijakan dan paradigma rekonstruksi.

Tingkat keterlibatan komunitas internasional dalam kedua proses perdamaian sangat tinggi terefleksikan dalam dana yang tersedia serta jumlah agensi dan staf internasional yang hadir di wilayah konflik dan bencana. Sebelum bencana tsunami, konflik Aceh telah menjadi "perang diam" (silent war), terisolasi dari dunia internasional karena keengganan pemerintah Indonesia untuk menginternasionalkan konflik, terutama setelah kemerdekaan Timor-Leste dari Indonesia. Namun, di Sri Lanka, selama tahun-tahun konflik, telah ada kehadiran lembaga internasional yang bertahan lama di daerah konflik di mana UNHCR dan berbagai INGO telah aktif selama bertahun-tahun karena masalah pengungsi dan kemanusiaan ${ }^{38}$. Di sisi lain,

\footnotetext{
37 John Darby. 2002. The Effect of Violence on

Process. Washiton DC: US Institute of Peace Press

${ }^{38}$ Darini Rajasingham-Senanayake. 2009.

Transnational Peace Building and Conflict: Lessons
} 
pemerintah Indonesia memiliki kebijakan ketat untuk mencegah organisasi internasional bekerja di Aceh di daerah konflik. Hanya setelah mengunjungi Aceh pada tanggal 27 Desember setelah bencana tsunami, Wakil Presiden Indonesia, Yusuf Kalla, ketika melihat kehancuran di provinsi tersebut, menyerukan bantuan internasional kepada sebuah provinsi yang dengan sengaja tetap terisolasi dalam konflik selama bertahun-tahun. Di sisi lain di Sri Lanka, pemerintah berturut-turut memiliki kebijakan pintu terbuka terhadap industri bantuan internasional dan, sepanjang konflik telah ada sejumlah PBB dan organisasi internasional yang bekerja di daerah yang terkena dampak konflik. Kehadiran komunitas internasional melalui bantuan internasional terus berkembang selama proses perdamaian dengan donasi sebesar US\$ 4,5 miliar, dan tumbuh lebih besar setelah tsunami. Sri Lanka memiliki reputasi selama ini sebagai pos "kesulitan" yang aman dan mudah di antara para pekerja bantuan.

Ada perbedaan mendasar dalam arsitektur bantuan internasional yang dikembangkan untuk mendukung proses perdamaian di kedua negara. Di Aceh, Misi Pemantau Aceh (AMM) yang dibentuk dengan kerangka waktu dan mandat yang jelas. AMM terdiri dari Uni Eropa dan observer yang berasal dari ASEAN. Di Sri Lanka terdapat kelompok observer Skandinavia yang dipimpin oleh Norwegia yang memiliki akses langsung kepada para mediator. Pada awal proses perdamaian, kelompok-kelompok hak asasi manusia menunjukkan fakta bahwa Sistem Pemantauan Sri Lanka (SLMM) perlu independen dari fasilitator proses perdamaian karena fasilitator tidak akan menjadi pemantau yang efektif, karena mereka menggunakan "carrot" daripada "stick" di pihak-pihak yang berkonflik. Pelanggaran gencatan senjata harus ditangani

from Aceh, Indonesia, and Sri Lanka. Journal of Social Issues in Southeast Asia, Vol. 24, No. 2 oleh kelompok independen dan fakta bahwa onserver UE dan ASEAN lebih mandiri di Aceh membantu proses perdamaian. Di Sri Lanka, SLMM mengalami kehilangan independensi dan kredibilitas karena kedekatannya dengan para mediator, dan ketika para pihak dalam konflik terlibat dalam pelanggaran, mereka tidak dapat berbuat banyak untuk mengatasinya secara independen pada jalur tertentu atau pada proses negosiasi yang lebih tinggi ${ }^{39}$.

Hal yang berbeda dari internasionalisasi proses perdamaian di kedua negara, bahwa di Aceh, proses perdamaian tidak terlalu diinternasionalisasi seperti pasca konflik dan operasi pemulihan tsunami di Sri Lanka. Karenanya, di Aceh terdapat kepemilikan lokal yang lebih baik terhadap proses perdamaian, termasuk oleh kelompok masyarakat sipil. Sementara itu, di Sri Lanka, proses perdamaian dan operasi pemulihan tsunami sebagian besar diserahkan kepada lembaga-lembaga internasional. Selain itu, keterlibatan internasional menempatkan biaya transaksi yang tinggi pada proses perdamaian itu sendiri ke titik bahwa kepemilikan lokal dan partispasi masyarakat sipil ke dalam proses perdamaian sangat terbatas. Di Indonesia, pemisahan dan keterkaitan reintegrasi pascakonflik dan rekonstruksi dari kegiatan pemulihan pasca-tsunami adalah salah satu alasan utama keberhasilan pembangunan perdamaian. Hal ini berarti aktor internasional dapat memainkan peran kontradiktif dalam situasi pasca konflik meskipun terdapat mekanisme koordinasi di antara komunitas internasional tersebut.

\section{Kesimpulan}

Bencana tsunami memberikan ruang kepada para aktor yang telibat dalam konflik untuk melakukan transformasi konflik menjadi

${ }^{39}$ Darini Rajasingham-Senanayake. 2009.

Transnational Peace Building and Conflict: Lessons from Aceh, Indonesia, and Sri Lanka. Journal of Social Issues in Southeast Asia, Vol. 24, No. 2 
Anita Afriani Sinulingga, Abdul Halim, Putiviola Elian Nasir | Bencana dan Konflik: Pelajaran dari Aceh dan Sri Lanka

perdamaian. Pada kasus Aceh dan Sri Lanka terlihat bahwa tren politik pasca bencana sangat penting dalam membentuk hasil konflik, meskipun kondisi-kondisi prabencana turut memberikan dampak. Transformasi konflik menuju perdamaian akan lebih kecil kemungkinannya di Aceh tanpa tsunami, sebaliknya, eskalasi kekerasan politik di Sri Lanka mungkin terjadi, bahkan tanpa adanya tsunami. Perdamaian di Aceh disebabkan melemahnya kekuatan kelompok GAM karena faktor kemiskinan yang semakin memburuk pasca-tsunami, kapasitas pemerintah Indonesia dalam menyelesaikan konflik dan pemulihan pasca-bencana, proses negosiasi yang terus menerus diupayakan bahkan sebelum bencana hingga kebijakan pemerintah Indonesia untuk tidak menginternasionalisasi konflik. Sementara di Sri Lanka, kemiskinan tidak mempengaruhi posisi kelompok LTTE untuk mempertahankan kekuasaannya. Konflik semakin memburuk Ketika pemerintah lemah dalam mengelola negaranya. Meskipun negosiasi juga telah diupayakan sebelum bencana namun negosiasi cenderung tidak berhasil disebabkan proses tersebut sepenuhnya diserahkan kepada lembaga-lembaga internasional sebagai dampak dari internasionalisasi konflik di Sri Lanka. 
Anita Afriani Sinulingga, Abdul Halim, Putiviola Elian Nasir | Bencana dan Konflik:

Pelajaran dari Aceh dan Sri Lanka

\section{DAFTAR PUSTAKA}

Aspinall, Edward, 2005. The Helsinki Agreement: A More Promising Basis for Peace in Aceh?". Policy Studies n20, Washington, DC: East-West Center

Bank Dunia. 2008. Dampak Konflik, Tsunami dan Rekonstruksi terhadap Kemiskinan di Aceh: Kajian Kemiskinan di Aceh tahun 2008. Jakarta: Bank Dunia

Barron, Patrick \& Clark, Samuel. 2006. Decentralizing Inequality? Center-Periphery Relations, Local Governance, and Conflict in Aceh. Conflict Prevention and Reconstruction Paper No. 39. Washington, D.C: World Bank.

Brancati, Dawn. 2007. Political Aftershocks: The impact of Earthquakes on Intrastate Conflict. Journal of Conflict Resolution, 51(5), 715-743

Collins, Andrew E. 2009. Disaster and Development. New York: Routledge

Daly, Patrick and dkk. Aceh Pascatsunami dan PascaKonflik. KITLV-Jakarta. 2012

Darby, John. 2002. The Effect of Violence on Process. Washington DC: US Institute of Peace Press

Deloughery, Elizabeth and dkk. Global Ecologies and the Environmental Humanities: Postcolonial Approaches. Abingdon: Routledge

Forced Migration Review. 2005. Tsunami: Learning From The Humanitarian Response. Special Issue

Gaillard, Jean-Christophe, and dkk. 2008. Wave of Peace? Tsunami disaster diplomacy in Aceh, Indonesia. Geoforum, 39(1), 511-526

Goodhand, Jonathan \& Klem, Bart. 2005. Aid, Conflict, and Peacebuilding in Sri Lanka 2000-2005. Sri Lanka: The Asia Foundation

Homer-Dixon, Thomas. 1999. Environment, Scarcity and Violence. Princeton: Princeton University Press

Jayasuriya, Sisira and dkk, 2006. Pemulihan Pasca-Tsunami: Masalah dan Tantangan di Sri Lanka, Jepang: Asian Development Bank Institute

Kelman, Illan. 2011. Disaster Diplomacy: How disasters affect peace and conflict. London: Routledge.

Kelman, Ilan. 2016. Catastrophe and Conflict: Disaster Diplomacy and Its Foreign Policy Implications. Brill Research Perspectives in Diplomacy and Foreign Policy, 1(1), 1-76

Kingsbury, Damien. 2006. Peace in Aceh: A Personal Account of the Helsinki Peace Process. 2006. Jakarta: PT Equinox Publishing Indonesia

Klitzsc, Nicole. 2014. Disaster Politics or Disaster of Politics? Post-tsunami Conflict Transformation in Sri Lanka and Aceh, Indonesia. Cooperation and Conflict, 49(4), 554-572

Lamont, Christopher.2015. Research Methods in International Relations. London: SAGE Publications Ltd

Le Billon, Philippe and Waizenegger, Arno. 2007. Peace in the Wake of Disaster? Secessionist Conflicts and the 2004 Indian Ocean Tsunami. Transactions of the Institute of British Geographers, 32(3), 411-427

Minear, L., \& Smith, H. 2007. Humanitarian Diplomacy Practitioners and Their Craft . New York: United Nations University.

Moleong, Lexy J. 2000. Metodologi Penelitian Kualitatif. Bandung: PT Remaja Posdakarya

Quarantelli, Enrico Louis. 1998. What is a Disaster? Perspectives in the Question. London and New York: Routledge 
Anita Afriani Sinulingga, Abdul Halim, Putiviola Elian Nasir | Bencana dan Konflik:

Pelajaran dari Aceh dan Sri Lanka

Rajasingham-Senanayake, Darini. 2009. Transnational Peace Building and Conflict: Lessons from Aceh, Indonesia, and Sri Lanka. Journal of Social Issues in Southeast Asia, 24(2), 211-235

Siddiqi, Ayesha. 2018. Disasters in Conflict Areas: Finding The Politics. Disaster, 42(S2), S161-S172

Slettebak, Rune T. 2012. Don't blame the weather! Climate-related natural disasters and civil conflict. Journal of Peace Research, 41(3), 163-176

Stokke, Kristian. 2005. After the tsunami: a missed opportunity for peace in Sri Lanka?. NIASnytt Asia Insights. Vol 2

Theisen, Ole Magnus and dkk. 2012. Climate Wars? Assessing the Claim That Drought Breeds Conflict. International Security, 36(3), 79-106

Uyangoda, Jayadeva. 2005. Ethnic conflict, the state and tsunami disaster in Sri Lanka. InterAsia Cultural Studies, 6(3), 341-52

Wieviorka, Michel. 2000. Contextualizing French Multiculturalism and Racism. Theory, Culture \& Society. Sage Journal, 17(1), 157-162 